\title{
The use of distillers' dry yeast as inoculum for rum fermentation on pilot plant scale'
}

\author{
Eduordo Cacho and Nivia F. Murphy ${ }^{2}$ \\ ABSTRACT
}

\begin{abstract}
The use of distillers' dried yeast as inoculum for rum fermentations was studied on a pilot plant scale. Two fermentation procedures (batch and fed batch) and four levels of dry yeast $(0.5,1.0,1.5$ and $2.0 \mathrm{~g} / \mathrm{h})$ were tested. The fermentations were followed for 36 hours. Product yields at 24 hours and 36 hours were determined. The resultant fermentation rate was below the rate required by the local industry (close to completion after 30 hours). This drawback is further complicated by the fact that dried yeast is not stable and has a shelf life that can vary from 1 to 12 months, depending on ambient storage conditions.
\end{abstract}

\section{RESUMEN}

\section{Levadura seca como inóculo para fermentar rones} a escala de planta piloto

Se estudió el uso de levadura seca como inóculo para fermentaciones de ron a escala de planta piloto; se probaron dos métodos de fermentación (por tandas y semicontinuo) y cuatro cantidades de levadura seca $\mathbf{0 . 5}$, $1.0,1.5$ y $2.0 \mathrm{~g} . / \mathrm{l}$.). Estas fermentaciones se observaron por 36 horas. Se calculó el rendimiento de etanol a las 24 y 36 horas. La fermentación fue menos rápida de lo que requiere la industria local: fermentación completa a las $\mathbf{3 0}$ horas. Este inconveniente se compliea porque la levadura va perdiendo actividad con el tiempo, ya que su utilidad, según indicado por el fabricante, fluctúa entre 1 a 12 meses según las condiciones de almacenamiento.

\section{INTRODUCTION}

The rum industry of Puerto Rico in 1986 generated $\$ 241.9$ million in excise taxes or $9 \%$ of our 1986 income. ${ }^{3}$ Traditionally, the Puerto Rican rum industry has used blackstrap molasses, a by-product of the sugar industry, as raw material because of its availability and price. The yeast inoculum is usually prepared by batch cell culture. The use of distiller's'

'Manuscript submitted to Editorial Board 28 October 1987.

'Assistant Chemical Engineer and Bacteriologist, Rum Pilot Plant, Agricultural Experiment Station, Mayagüez Campus, University of Puerto Rico, Río Piedras, P. R. The authors thank Amador Belardo, Technical Director, Rum Pilot Plant, for his advice; Zulma de Ayala, Carmen L. Cacho and Maria M. Calderón of the Chemistry Section for their help in the analytical work.

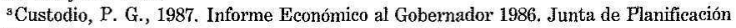
de Puerto Rico. 
dry yeast as inoculum for fermentations was studied to determine its feasibility and desirability. This practice, if successful, could be used as an alternative to the conventional method. It is specially appropriate for speeding a plant start-up after a shut-down. This technique would also be convenient for the laboratory and pilot plant fermentation studies since the whole procedure of preparing the seed inoculum would be eliminated thus shortening each run by several days and eliminating a possible source of experimental error.

\section{MATERIALS AND METHODS}

Equipment

Fermentations were carried out in $3785 \mathrm{~L}$ (working capacity) tanks with covered tops to achieve anaerobic conditions. These tanks were equipped with a 2-inch diameter outlet for release of the $\mathrm{CO}_{2}$ generated, a $65 \mathrm{ft}^{2}$ surface area coil for cooling water, a sight gage for measuring liquid level, a thermometer, and $1.5 \mathrm{hp}$ centrifugal pump for recirculating the fermenting broth. We added the molasses mash at a constant rate by pumping it from a $1900 \mathrm{~L}$ (working capacity) tank with sanitary metering pump equipped with a $3 / 4 \mathrm{hp}$ variable speed drive. Flow rate was adjusted manually and measured with a rotameter. The molasses mash and fermented broth were centrifuged with a Westfalia Separator Model NS-7-06-076.4 Distillation was performed with the Rum Pilot Plant Beer Column. Aside from the distillation column, all other materials of construction in direct contact with the molasses mash or broth were of type 316 stainless steel.

\section{Experimental procedure}

Eight experiments were run with dry yeast (Red Star') as inoculum; two fermentation modes (batch and fed batch) and four levels of dry yeast were tested (table 1). Since this is an application that could be very easily adapted by industrial outfits, the conditions chosen were those prevalent in industry, i.e., usage of black-strap molasses, sugar level to obtain a $12 \%(\mathrm{v} / \mathrm{v})$ alcohol, adjustment of $\mathrm{pH}$ to 4.7 , and no pretreatment of molasses mash. Ammonium sulfate $(1.5 \mathrm{~g} / \mathrm{L})$. was used as nutrient.

Initially all the equipment was sterilized with live steam. The fermentation feed consisted of a ca. $50 \mathrm{~g} / 100 \mathrm{ml}$ fermentable sugar solution. Ammonium sulfate $1.5 \mathrm{~g} / \mathrm{L}$, was added as nitrogen source; $\mathrm{pH}$ was adjusted with sulfuric acid to 4.7. The fermentor was first charged with the amount of tap water required for each experiment. Subsequently, the dry yeast inoculum was added, followed by the molasses feed, which was

«Trade names in this publication are used only to provide specific information. Mention of a trade name does not constitute a warranty of equipment of materials by the Agricultural Experiment Station of the University of Puerto Rico, nor is this mention a statement of preference over other equipment or matexials. 
added in one step for the batch runs, and in $\mathbf{1 6}$ hours at a constant rate for the fed batch runs. The final volume for all the runs was $3785 \mathrm{~L}$.

All the fermentations were followed for 36 hours starting from the molasses feed addition. Throughout the experiment the recirculating pump was running and the temperature in the fermenter was kept at 86 $\pm 2^{\circ} \mathbf{F}\left(30^{\circ} \mathrm{C}\right)$ with cooling water through the inner coil.

To monitor the process, we drew samples every 4 hours and analyzed for total sugars $(\mathrm{g} / 100 \mathrm{ml})$, percentage alcohol $(\mathrm{v} / \mathrm{v})$, total acidity $(\mathrm{g} / \mathrm{L})$, and $\mathrm{pH}$ as described in the Official Analytical Methods of the Rum Pilot Plant. ${ }^{5}$ To stop the fermentation, we added $2 \mathrm{~g} / \mathrm{L}$ of mercuric chloride to the samples. At the end of 36 hours, the fermentation broth was centrifuged and then distilled. To keep interfering variables to a minimum, we calculated with samples before centrifugation and distillation.

\section{RESULTS AND DISCUSSION}

Table 1 includes the results for percentage yield at 24 and 36 hours of the dry yeast study. Fed-batch runs showed greater conversion than batch runs, but this difference starts diminishing as dry yeast levels increase and is small for the $2 \mathrm{~g} / \mathrm{L}$ level after 36 hours (63.09 vs. 68.73). By observation of the fed-batch runs at 36 hours, we concluded that there are no significant advantages in using levels beyond $1.5 \mathrm{~g} / \mathrm{L}$ for this fermentation mode (fig. 1).

The manufacturer of the distillers dry yeast (Red Star) recommends a $0.5 \mathrm{~g} / \mathrm{L}$ level for industrial usage. At this level and even at levels of 1.5 $\mathrm{g} / \mathrm{L}$ (fed-batch) the resultant fermentation rate is below the rate required by the local industry (close to completion after 30 hours). This drawback is complicated because the dry yeast is not very stable and has a shelf life recommended by the manufacturer that can vary from 1-12 months, depending on ambient storage conditions.

TABLE 1.-Alcoholic \% yield at 24 and 36 hours as a function of dry yeast level and fermentation mode for blackstrap molasses fermentations

\begin{tabular}{ccccc}
\hline Experiment No. & Fermentation mode & Dry yeast level & 24 hours & 3ield hours \\
\hline 38 & Batch & $0.5 \mathrm{~g} / \mathrm{L}$ & 19.86 & 38.57 \\
34 & Batch & $1.0 \mathrm{~g} / \mathrm{L}$ & 42.78 & 43.54 \\
37 & Batch & $1.5 \mathrm{~g} / \mathrm{L}$ & 28.35 & 52.10 \\
38 & Batch & $2.0 \mathrm{~g} / \mathrm{L}$ & 44.32 & 63.09 \\
35 & Fed-Batch & $0.5 \mathrm{~g} / \mathrm{L}$ & 29.47 & 46.30 \\
36 & Fed-Batch & $1.0 \mathrm{~g} / \mathrm{L}$ & 42.02 & 58.04 \\
39 & Fed-Batch & $1.5 \mathrm{~g} / \mathrm{L}$ & 46.59 & 68.56 \\
40 & Fed-Batch & $2.0 \mathrm{~g} / \mathrm{L}$ & 52.77 & 68.73 \\
\hline
\end{tabular}

sOffieial Analytical Methods of the Rum Pilot Plant, 1969. Agric. Exp. Stn., Univ. P. R., Río Piedras, P. R. 


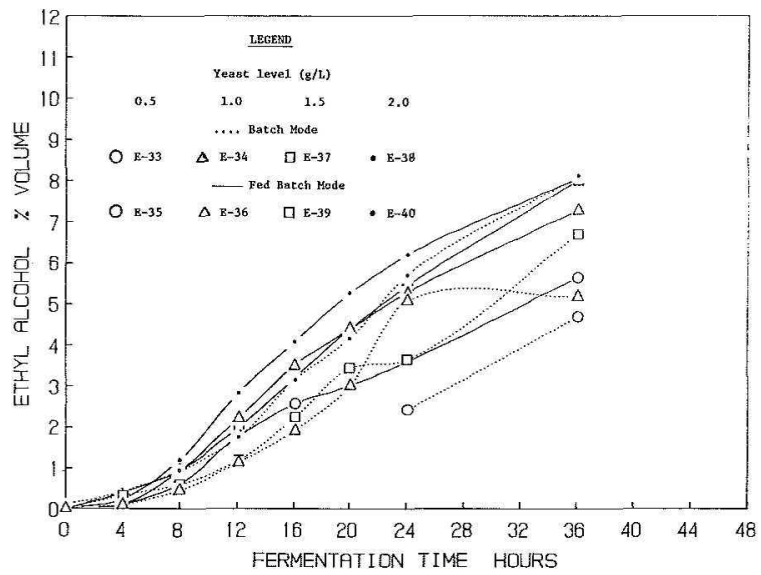

FIG. 1.-Alcohol as a function of time for different yeast levels and fermentation procedures.

We studied the possibility that this distiller's' dry yeast was intrinsically slower in blackstrap molasses fermentation than the yeasts used for rum production in this laboratory. Our yeasts have been screened over the years and selected on the basis of yield, rate of fermentation and quality of product. We isolated the distillers' dry yeast (PPR 302) in an agar plate of synthetic medium ${ }^{6}$ in laboratory scale fermentations and compared it with one of our selected yeasts (PPR 80). We used traditional seed propagation methods. ${ }^{7}$ Better performance in terms of rate and yield was observed again with our selected yeast. The manufacturer is willing to elaborate dry yeast with our yeast strains. It seems reasonable to believe that if one of our selected yeasts is prepared in dry form, the performance will improve.

"Official Bacteriological Methods of the Rum Pilot Plant, 1969. Agric. Exp. Stn., Univ. P. R., Río Piedras, P. R.

${ }^{7}$ Murphy, N., 1984. Fermentation of high test molasses. J. Agric. Univ. P. R., 68 (1): 33-44. 